nhóm có canxi ion giảm $(92,6 \%)$, sự khác biệt này có ý nghĩa thống kê $(p=0,0001<0,05)$.

Tình trạng hoạt động bệnh và mức độ hoạt động bệnh được thể hiện qua thang điểm đánh giá mức độ đau VAS, chỉ số đánh giá viêm (CRP) và chỉ số BASDAI. Kết quả nghiên cứu của chúng tôi thể hiện ở biểu đồ 4 , biểu đồ 5 và biểu đồ 6 cho thấy tỉ lệ thiếu vitamin $D$ ở nhóm đối tượng nghiên cứu có mức độ đau vừa hoặc nặng (90,5\%) cao hơn so với nhóm đối tượng nghiên cứu có mức độ đau nhẹ $(52,2 \%)$, ở nhóm có chỉ số CRP tăng tỉ lệ thiếu vitamin $D$ là $71,7 \%$ cũng cao hơn nhóm có chỉ số CRP bình thường (47,6\%). Tương tự như vậy, tỷ lệ thiếu vitamin D ở nhóm đối tượng nghiên cứu có chỉ số BASDAI thấp (không hoạt động bệnh) là 54,9\% thấp hơn so với tỉ lệ thiểu vitamin $D$ ở nhóm có chỉ số BASDAI cao (đang hoạt dộng bệnh) (93,8\%). Có sự liên quan giữa tình trạng thiếu vitamin $D$ với mức độ đau (VAS), chỉ số CRP và chỉ số BASDAI $(p<0,05)$. Kết quả nghiên cứu này tương tự với nghiên cứu của ZHAO và cộng sự công bố năm 2017 khi nghiên cứu trên 235 bệnh nhân viêm khớp - cột sống thể trục tại Anh cho thấy sự thiếu hụt vitamin $D$ có liên quan đến mức độ đau (VAS) (OR=1,21,95\%, CI: 1,07-1,38), chỉ số CRP (OR= 1,02, CI 95\%: 1,01-1,04,) chỉ số hoạt động bệnh BASDAI (OR=1,23, 95\% CI: 1,06 - 1,41).

\section{KẾT LUẬN}

Tình trạng thiếu hụt vitamin $D$ gặp khá phổ biến ở bệnh nhân viêm khớp - cột sống. Sự thiếu hụt này càng tăng lên khi người bệnh có thời gian mắc bệnh kéo dài hoặc có các dấu hiệu bệnh đang hoạt động mạnh như mức độ đau vừa hoặc nặng (tăng điểm VAS), các chỉ số CRP và BASDAI tăng cao. Do đó, xét nghiệm định lượng nồng độ vitamin $D$ là cần thiết, giúp cho các thày thuốc lâm sàng có thể bổ sung vitamin D sớm cho các đối tượng này.

\section{TÀI LIÊUU THAM KHẢO}

1. Durmus B, Altay Z, Baysal O, Ersoy Y. Does vitamin D affect disease severity in patients with ankylosing spondylitis? Chin Med J (Engl). 2012;125(14):2511-2515.

2. Vitamin $D$ treatment for connective tissue diseases: hope beyond the hype? | Rheumatology | Oxford Academic. Accessed May 22, 2020. https://academic.oup.com/rheumatology/article/56 /2/178/2631547

3. Crotti $C$, Becciolini $A$, Biggioggero $M$, Favalli EG. Vitamin D and Spondyloarthritis: Review of the Literature. Open Rheumatol J. 2018;12(1). doi:10.2174/1874312901812010214

4. Fernandes $\mathbf{S}$, Etcheto $\mathbf{A}$. Vitamin $D$ status in spondyloarthritis: results of the ASAS-COMOSPA international study. Clin Exp Rheumatol. Published online 2018:5.

5. Vitamin-D-deficiency.pdf. Accessed September 4, 2021. http://www.beauty-review.nl/wp-content/ uploads/2015/04/Vitamin-D-deficiency.pdf

6. Ismail M F, El-Mansoury TM, Abd El-Karim AH, et al. Vitamin D status in ankylosing spondylitis patients: Relation to bone health, disease activity, functional status, spine mobility and enthesitis. Egypt Rheumatol. 2020;42(4):291295. doi:10.1016/j.ejr.2020.08.005

7. Guła $Z$, Kopczyńska A, Hańska $K$, et al. Vitamin D serum concentration is not related to the activity of spondyloarthritis - preliminary study. Reumatologia. 2018;56(6):388-391. doi:10.5114/ reum.2018.80717

8. Ho-Pham L, Nguyen $\mathbf{N}$, Lai $T$, Eisman J, Nguyen $\mathbf{T}$. Vitamin $\mathrm{D}$ status and parathyroid hormone in a urban population in Vietnam. Osteoporos Int J Establ Result Coop Eur Found Osteoporos Natl Osteoporos Found USA. 2010;22:241-248. doi:10.1007/s00198-010-1207-4

\title{
ĐĂC ĐIỂM LÂM SÀNG VÀ TÌNH TRANG DI CĂN HẠCH CỦA VI UNG THƯ TUYẾN GIÁP THỂ NHÚ
}

\section{TÓM TẮT.}

Mục tiêu: đánh giá đặc điểm lâm sàng và tình trạng di căn hạch của vi ung thư tuyến giáp thể nhú tại bệnh viện Đại học Y Hà Nội. Đối tượng và

${ }^{1}$ Bệnh viện Đại học Y Hà Nội

Chịu trách nhiệm chính: Nguyễn Xuân Hậu

Email: nguyenxuanhau@hmu.edu.vn

Ngày nhận bài: 6.7.2021

Ngày phản biện khoa học: 31.8.2021

Ngày duyệt bằi: 10.9.2021
Nguyễn Xuân Hậu ${ }^{1}$

phương pháp: Nghiên cứu mô tả trên 80 bệnh nhân đưỡc chẩn đoán vi ung thư tuyến giáp thể nhú, được phẩu thuật tại bệnh viện Đại học Y Hà Nội tữ tháng $3 / 2016$ đến tháng 1/2020. Kết quả: Tỉ lệ sờ thấy u trên lâm sàng là $39,8 \%$, u ở 1 thùy $93,7 \%$. hạch cổ trên lâm sàng 14,9. U trên siêu âm 100\%, u TIRADS 4 chiếm 77,6\%. Hạch trên siêu âm 25,5\%; hạch cổ bên $65,9 \%$, trong đó mất cấu trúc xoang hạch $68,3 \%$, vôi hóa trong hạch $31,7 \%$. FNA khối u $100 \%$, kết quả dương tính $77 \%$, nghi ngờ 18,3\%, âm tính 4,7\%. Kết luận: Vi ung thư tuyến giáp thể nhú chủ yếu phát hiện qua khám sức khỏe định kỳ, bệnh ít triệu chứng, 
ít di căn hạch trên lâm sàng.

Tứ khóa: vi ung thư tuyến giáp thể nhú, đặc điểm lâm sàng, di căn hạch

\section{SUMMARY}

CLINICAL FEATURES AND CERVICAL LYMPH NODES METASTAIS OF PAPILLARY THYROID MICROCACINOMA

Objective: To evaluate the clinical features and cervical lymph node metastasis of papillary thyroid carcinoma at Hanoi medical university hospital. Subjects and Methods: A retrospective study on 80 patients were diagnosed with papilary thyroid microcarcinoma, operated at Hanoi medical university hospital from March 2016 to January 2020. Results: Clinical palpation of tumors rate were $39.8 \%$, unilateral tumor rate were $93.7 \%$, clinical cervical lymph nodes rate were $14.9 \%$. The tumor detection rate on ultrasound were $100 \%$, of which TIRADS 4 were $77.6 \%$, lymph nodes on ultrasound were $25,5 \%$. of which, the lateral cervical lymph node rate were $65.9 \%$, The rate of loss of hilar lymph node were $68.3 \%$, the rate of calcification in the lymph nodes were $31.7 \%$. All patients have been FNA, positive results accounted for $77 \%$, suspected rate accounted for $18.3 \%$, negative results accounting for $4.7 \%$. Conclusion: Almost micropapillary carcinoma are diagnosed by screening, lack of symtom, clinical cervical lymph node metastasis are less.

Keywords: micropapillary carcinoma, clinical feature, cervical lymph node metastasis

\section{I. ĐẶT VẤN ĐỀ}

Vi ung thư tuyến giáp thể nhú (PTMC) được định nghĩa là khối u tuyến giáp có kích thước đường kính lớn nhất không quá $1 \mathrm{~cm}$, được xác định trên giải phẫu bệnh lý là ung thư biểu mô tuyến giáp thể nhú1. Là thể thường gặp nhất trong các thể ung thư tuyến giáp $(85 \%)^{2}$. Vi ung thư tuyến giáp thể nhú đa phần tiến triển thầm lặng không có biểu hiện lâm sàng. Chẩn đoán vi ung thư tuyến giáp thể nhú thường dựa vào siêuu âm và chọc hút kim nhỏ (FNA) dưới hướng dẫn của siêu ẩm. Mặc dù tiên lượng của nhóm bệnh nhân PTMC là rất tốt, tuy nhiên những trường hợp di căn hạch, đặc biệt là nhóm hạch cổ trung tâm khá phố biến và xảy ra với tỉ lệ từ $12 \%$ đến $64 \%{ }^{3}$. Di căn hạch cổ được xem như yếu tố tiên lượng xấu cho khả năng tái phát tại chỗ và thời gian sống thêm ${ }^{4}$.

\section{II. ĐỐI TƯƠNG VÀ PHƯƠNG PHÁP NGHIÊN CỨU}

2.1. Đối tượng nghiên cứu: Nghiên cứu được thực hiện trên 80 bệnh nhân được chẩn đoán vi ung thư biểu mô tuyến giáp thể nhú và điều trị tại khoa Ung bướu và chăm sóc giảm nhẹ bệnh viện Đại học Y Hà Nội từ tháng 3/2016 đến tháng $1 / 2020$.

Tiêu chuẩn lựa chọn bệnh nhân
+ chẩn đoán trước mổ là vi ung thư tuyến giáp thể nhú, sau phẫu thuật có kết quả xét nghiệm giải phẫu bệnh khẳng định là vi ung thư biểu mô tuyến giáp thể nhú.

+ Hồ sơ bệnh án đầy đủ thông tin: trước, trong và sau phẫu thuật.

+ Bệnh nhân đồng ý tham gia nghiên cứu

Tiêu chuẩn loại trừ: không đáp ứng tiêu chuẩn trên

2.2. Phương pháp nghiên cứu: Nghiên cứu mô tả

\subsection{Các chỉ số nghiên cứu:}

+ Đặc điểm lâm sàng, cận lâm sàng bệnh nhân có vi ung thư tuyến giáp thể nhú (Tuổi, giới, thời gian phát hiện bệnh, lý do vào viện, đặc điểm u và hạch cổ trển lâm sàng và trên siêu âm, kết quả chọc hút tế bào trước mổ).

+ Kết quả giải phẫu bệnh sau mổ (u và hạch cổ, tỷ lệ phát hiện hạch trên lâm sàng và siêu âm), mối liên quan giữa hạch cổ khoang trung tâm và các yếu tố nguy cơ.

\section{KẾT QUẢ NGHIÊN CỨU}

Tuổi và giới: tuổi trung bình là 44,6 tuổi, nữ giới chiếm tỉ lệ 85,1.

Lý do vào viện: Đa số bệnh nhân khám sức khỏe phát hiện u giáp, chiếm tỉ lệ trên $90 \%$.

Đặc điểm u tuyến giáp trên lâm sàng: Tỷ lệ sờ thấy u trên lâm sàng khoảng $40 \%$, mật độ u thường cứng chắc và di động

Đặc điểm u tuyến giáp trên siêu âm

Bảng 1. Đặc điểm u tuyến giáp trên siêu âm

\begin{tabular}{|c|c|c|c|}
\hline \multicolumn{2}{|c|}{$\begin{array}{l}\text { Đặc điếm u tuyến giáp } \\
\text { trên siêu âm }\end{array}$} & $\begin{array}{l}\text { Số } \\
\text { BN }\end{array}$ & $\begin{array}{c}\text { Tỉ lệ } \\
\text { \% }\end{array}$ \\
\hline \multirow{2}{*}{$\begin{array}{c}\text { Số } \\
\text { lượng u }\end{array}$} & Có $1 \mathrm{u}$ & 47 & 58,4 \\
\hline & $\geq 2 \mathrm{u}$ & 33 & 41,6 \\
\hline \multirow{5}{*}{ Vị trí u } & Thùy phải & 34 & 42,2 \\
\hline & Thùy trái & 15 & 18 \\
\hline & Cả 2 thùy & 26 & 32,3 \\
\hline & Eo giáp & 4 & 5,6 \\
\hline & Thùy và eo giáp & 1 & 1,9 \\
\hline \multirow{2}{*}{$\begin{array}{c}\text { Kích } \\
\text { thước u }\end{array}$} & $\leq 0,5 \mathrm{~cm}$ & 32 & 40,4 \\
\hline & $0,5-1 \mathrm{~cm}$ & 48 & 59,6 \\
\hline \multirow{3}{*}{$\begin{array}{c}\text { Âm } \\
\text { vang u }\end{array}$} & Giảm âm & 63 & 78,9 \\
\hline & Tăng âm & 1 & 1,2 \\
\hline & Hôn hợp âm & 16 & 19,9 \\
\hline \multirow{2}{*}{$\begin{array}{l}\text { Vi vôi hóa } \\
\text { tại u }\end{array}$} & Có & 48 & 59,6 \\
\hline & Không & 32 & 40,4 \\
\hline \multirow{5}{*}{ TIRADS } & 3 & 9 & 11,2 \\
\hline & $4 a$ & 28 & 34,8 \\
\hline & $4 b$ & 27 & 33,5 \\
\hline & $4 c$ & 7 & 9,3 \\
\hline & 5 & 9 & 11,2 \\
\hline
\end{tabular}

Đa số gặp 1 khối u trên siêu âm, phần lớn u 
nằm ở 1 thùy tuyến giáp, kích thước hay gặp $0,5-1 \mathrm{~cm}$, u có tính chất giảm âm chiếm tỉ lệ cao, phân lớn có cấu trúc vi vôi hóa trong u

Đặc điểm hạch cổ trên lâm sàng: Hầu hết các bệnh nhân không phát hiện được hạch cổ qua khám lâm sàng

Đặc điểm hạch cổ trên siêu âm: tỷ lệ phát hiện hạch trên siêu âm là $25.5 \%$, vôi hóa trong hạch chiếm $31,7 \%$, mất cấu trúc xoang chiếm $68.3 \%$.

Kết quả di căn hạch sau phẫu thuâât:

Bảng 2. Kết quả dí căn hạch sau phẩu thuật

Kết quả di căn hạch sau phẫu thuật
Số

Tile

\begin{tabular}{|c|c|c|c|}
\hline \multirow{2}{*}{$\begin{array}{c}\text { Vị trí hạch di } \\
\text { căn hạch } \\
(\mathrm{n}=28)\end{array}$} & $\begin{array}{c}\text { Nhóm trung tâm } \\
\text { đơn thuân }\end{array}$ & 16 & 56,1 \\
\cline { 2 - 4 } & $\begin{array}{c}\text { Nhóm hạch cố } \\
\text { bên đơn thuần }\end{array}$ & 3 & 10,5 \\
\cline { 2 - 4 } & $\begin{array}{c}\text { Nhóm trung tâm } \\
\text { + hạch cố bên }\end{array}$ & 9 & 33,3 \\
\hline $\begin{array}{c}\text { Không phát } \\
\text { hiện hạch trước } \\
\text { mổ (n=40) }\end{array}$ & Không di căn hạch & 27 & 66,2 \\
\hline & Có di căn hạch & 13 & 33,8 \\
\hline
\end{tabular}

Trong số những bênh nhân có di căn hach, phần lớn các trường hợp là di căn hạch nhóm trung tâm, đơn thuần hoặc đồng thời với nhóm hạch cổ bên.

Tỷ lệ di căn hạch tiềm ẩn ở những bệnh nhân không phát hiện hạch trước mổ khoảng 33.8\%

Bảng 3. Môi liên quan giữa tỉ lệ di căn hạch cổ nhóm trung tâm và các yêu tố

\begin{tabular}{|c|c|c|c|c|}
\hline \multirow{2}{*}{\multicolumn{2}{|c|}{ Đặc điểm }} & \multicolumn{2}{|c|}{ Tình trạng di căn hạch } & \multirow{2}{*}{$\begin{array}{l}\text { Giá trị p } \\
\text { ( ttest) }\end{array}$} \\
\hline & & Có di căn hạch & Không di căn hạch & \\
\hline \multirow{2}{*}{ Tuổi } & $\leq 55$ & $22(42,3 \%)$ & $30(57,7 \%)$ & \multirow{2}{*}{0,892} \\
\hline & $>55$ & $3(41,2 \%)$ & $5(58,8 \%)$ & \\
\hline \multirow{2}{*}{ Giới } & Nũ̃ & $22(41,5 \%)$ & $31(58,5 \%)$ & \multirow{2}{*}{0,783} \\
\hline & Nam & $3(46,7 \%)$ & $4(53,3 \%)$ & \\
\hline \multirow{2}{*}{$\begin{array}{l}\text { Ung thư } \\
\text { hai thùy }\end{array}$} & Không & $17(36,8 \%)$ & $30(63,2 \%)$ & \multirow{2}{*}{0,027} \\
\hline & Có & $8(66,7 \%)$ & $5(33,3 \%)$ & \\
\hline \multirow{2}{*}{$\begin{array}{l}\text { Tình trạng } \\
\text { phá võ vó }\end{array}$} & Có & $9(63,3 \%)$ & $6(36,7 \%)$ & \multirow{2}{*}{0,02} \\
\hline & Không & $16(35,2 \%)$ & $29(64,8 \%)$ & \\
\hline \multirow{2}{*}{ Đa ổ } & Có & $9(47,5 \%)$ & $11(52,5 \%)$ & \multirow{2}{*}{0,438} \\
\hline & Không & $16(39,5 \%)$ & $24(60,5 \%)$ & \\
\hline \multirow{2}{*}{ Kích thước u } & $\leq 0,5 \mathrm{~cm}$ & $7(26,4 \%)$ & $20(73,6 \%)$ & \multirow{2}{*}{0,003} \\
\hline & $>0,5-1 \mathrm{~cm}$ & $18(54,4 \%)$ & $15(45,6 \%)$ & \\
\hline
\end{tabular}

Tỉ lệ di căn hạch cao hơn ở các trường hợp tuối $\leq 55$, ung thư hai thùy, u phá vỡ vỏ, tổn thương đa ổ và kích thước $u>0,5 \mathrm{~cm}$. Trong đó kích thước $\mathrm{u}>0,5 \mathrm{~cm}$, ung thư hai thùy và tình trạng phá võ̃ vỏ làm tăng tỉ lệ di căn hạch một cách có ý nghĩa thống kê $(p<0,05)$.

\section{BÀN LUẬN}

Đa số bệnh nhân trong nghiên cứu của chúng tôi đến viện vì tình cờ phát hiện khối u giáp qua khám sàng lọc $(92,5 \%)$. Kết quả này cao hơn so với nghiên cứu của Hoàng Huy Hùng (2016) $18,4 \% 5$. Bệnh chủ yếu gặp ở nữ giới với tỉ lệ nữ/nam là $5,7 / 1$. Kết quả của chúng tôi cao hơn so với một số nghiên cứu khác như của SEER trên hơn 14000 bệnh nhân PTMC, tỉ lệ nữ/nam là 4,3/1, của Giordano (2009) tỉ lệ nữ/nam là 2,2/1, nghiên cứu của Zhang-zhi Lu (2015) là 3,85/16. Độ tuổi trung bình của nhóm bệnh nhân là 44,60 $\pm 10,53$, chủ yếu ở nhóm tuổi $<55$ với tî lệ $86,3 \%$. Kết quả này phù hợp với nghiên cứu của Roti Ellio trên 243 bệnh nhần vi ung thư giáp thể nhú, độ tuổi trung bình là $42.5 \pm 15.1$, nhóm tuổi dưới 45 chiếm $69,13 \% \%^{7}$. Theo nghiên cứu của tác giả Lê Văn Quảng và Ngô Quốc Duy (2019) trên 306 bệnh nhân PTMC, tuổi trung bình của nhóm là $45.3 \pm 10.7$ năm và $81,05 \%$ bệnh nhân dưới 55 tuổi ${ }^{8}$.

Tỉ lệ sờ thấy u và hạch qua khám lâm sàng là $39,8 \%$ và $14,9 \%$. Các khối u được phân loại trên siêu âm chủ yếu là TIRADS $4(77,6 \%)$ với các đặc điểm trên siêu âm hay gặp là giảm âm và có vi vôi hóa $(78,9 \% ; 59,6 \%)$, ranh giới không đều, mật độ đặc. Trong nghiên cứu của chúng tôi có 41 bệnh nhân $(25,5 \%)$ được phát hiện có hạch nghi ngờ trên siêu âm. Tỉ lệ di căn hạch của 41 bệnh nhân này là $70,7 \%$. Trong nghiển cứu của chúng tôi tỉ lệ chọc hút tế bào bằng kim nhỏ chẩn đoán ác tính đối với u tuyến giáp là $77 \%$, có $18,3 \%$ trường hợp nghi ngờ và 5 trường hợp âm tính giả chiếm $4,7 \%$. Tî lệ di căn hạch cổ nhóm trung tâm ở những bệnh nhân được chỉ định vét hạch cổ là $42,1 \%$. Di căn hạch nhóm trung tâm thường gặp hơn ở các trường hợp nam giới, tuổi $\leq 45$, ung thư hai thùy, u phá võ vỏ xâm lấn ngoài tuyến, tổn thương đa ổ và kích thước $u>0,5 \mathrm{~cm}$ đến $1 \mathrm{~cm}$. Bởi vậy, đánh giá kĩ 
các yếu tố nguy cơ cao có giá trị tiên lượng về di căn hạch sẽ giúp xác định được chiến lược điều trị phù hợp.

\section{KẾT LUÂN}

Vi ung thư tuyến giáp thể nhú thường được tình cờ phát hiện qua khám sức khỏe định kỳ, chủ yễu gặp ở nữ giới dưới 45 tuổi. Tỉ lệ di căn hạch của nhóm bệnh nhân này là $70,7 \%$. Tỉ lệ chọc hút tế bào bẳng kim nhỏ chẩn đoán ác tính với u tuyến giáp chiếm $77 \%$, các trường hợp âm tính giả được làm sinh thiết tức thì trong mổ cho kết quả dương tính.

Di căn hạch cổ khoang trung tâm thường gặp ở nam giới trẻ tuổi $(<45)$, ung thư 2 thùy, u phá võ vỏ xâm lấn ngoài tuyến, tổn thương đa ổ và kích thước u trên $0,5 \mathrm{~cm}$.

\section{TÀI LIÊU THAM KHẢO}

1. C.W.E Hedinger, L.H Son (1988). WHO histologic typing of thyroid tumors. ApringerVerlag, New York.

2. D Karakoc, A Ozdemir (2010). Lymph Node Surgery in Papillary Thyroid Carcinoma. Int Surg, 95, $142-146$.
3. Lee Kwan Ju, Cho Yun Jung, Kim Say Jun, et al. (2011). Analysis of the clinicopathologic features of papillary thyroid microcarcinoma based on 7-mm tumor size. World journal of surgery, 35(2), 318-323.

4. Hwang Harry S, Orloff Lisa A (2011). Efficacy of preoperative neck ultrasound in the detection of cervical lymph node metastasis from thyroid cancer. The Laryngoscope, 121(3), 487-491.

5. Hoàng Huy Hừng (2016). Đánh giá di căn hạch của ung thư biểu mô tuyến giáp, Trường Đại học $Y$ Hà Nội, Hà Nội.

6. Lu Zhong-Zhi, Zhang Yan, Wei Song-Feng, et al. (2015). Outcome of papillary thyroid microcarcinoma: Study of 1,990 cases. Molecular and clinical oncology, 3(3), 672-676.

7. Roti Elio, Rossi Roberta, Trasforini Giorgio, et al. (2006). Clinical and histological characteristics of papillary thyroid microcarcinoma: results of a retrospective study in 243 patients. The Journal of Clinical Endocrinology \& Metabolism, 91(6), 2171-2178.

8. Lê Văn Quảng, Ngô Quốc Duy, Mai Thế Vương, và công sư (2019). Đánh giá các yếu tố ảnh hưởng tới tỉnh trạng di căn hach nhóm 6 ở bệnh nhân vi ung thư biểu mô tuyển giáp thể nhú giai đoạn cNO. Tạp chí Ung thư học Việt Nam, Số 1 - 2019.

\section{KẾT QUẢ PHẪU THUÂT NộI SOI LỒNG NGỰC MộT LỖ ĐIỀU TRI UNG THƯ PHỔI KHÔNG TẾ BÀO NHỎ GIAI ĐOAN SỚM TẠI BỆNH VIỆN HỮU NGHI VIỆT ĐỨC}

\section{TÓM TẮT}

Đắt vấn đề: Ung thư phổi là một trong những ung thư thường gặp nhất và là nguyển nhân gây tử vong hàng đâu trển thế giới. Phâuu thuật là phương pháp điêu trị được lựa chọn đầu tiên đối với ung thư phổi không tế bào nhỏ giai đoạn sớm (I, II) trong đó có phẫu thuật nội soi một lỗ. Tại bệnh viện hữu nghị Việt Đức đã triển khai thường qui phẫu thuâtt này và có những tổng kết bước đầu nhưng vẫn cần có tổng kết và đánh giá kết quả một cách tổng quan của phương pháp. Phương pháp: Nghiên cứu mô tả, hồi cứu 37 bệnh nhân ung thư phổi không tế bào nhỏ giai đoạn sớm được điều trị bằng phẫu thuật nội soi lồng ngực môt lỗ từ tháng 01/2016 tới $06 / 2021$ về các thộng số trước, trong và sau mổ cùng kết quả giải phẫu bệnh.... Kết quả: Bao gồm 21 nam và 16 nữ.

${ }^{1}$ Đai hoc Y Hà Nọi

${ }^{2}$ Bệnh viện Hữu nghi Việt Đức

${ }^{3}$ Bệnh viện đa khoa tỉnh Yên Bái

Chịu trách nhiệm chính: Phạm Hữu Lư

Email: phamhuulu@hmu.edu.vn

Ngày nhận bài: 12.7.2021

Ngày phản biên khoa hoc: 6.9.2021

Ngày duyệt bài: 13.9.2021

\section{Phạm Hữu Lư ${ }^{1,2}$, Nguyễn Mạnh Hiệp ${ }^{3}$}

Tuổi trung bình 59,62 $\pm 8,79$ (34 - 76). Kích thước khối u trung bình 2,97 cm, trong đó kích thước nhỏ nhất $1 \mathrm{~cm}$; lớn nhất $5 \mathrm{~cm}$. Thời gian phẫu thuât $150 \pm$ 22,58 phút (90-195). Thời gian rút dấn lưu màng phổi trung bình $5,59 \pm 1,46$ ngày (3- 9 ). Số ngày nằm viện trung bình 7,54 $\pm 1,86$ ngày (4-12). Không có tử vong, tai biến và biến chứng nặng trong và sau mổ. Kết quả giải phẫu bệnh sau mổ: 34 ung thư biểu mô tuyến và 2 ung thư biểu mô vảy, 1 ung thư khác. Giai đoạn ung thư: 18 trường hợp giai đoạn I, 19 trường hợp giai đoạn II. Kết luận: Điều trị ung thư phổi không tế bào nhỏ giai đoạn sớm bằng phẫu thuật nội soi lồng ngực một lố là một phương pháp an toàn, khả thi và có nhiều ưu điểm.

Tư khóa: Ung thư phổi không tế bào nhỏ, phẫu thuật nội soi lồng ngực một lỗ

\section{SUMMARY}

\section{RESULTS OF UNIPORTAL VIDEO-ASSISTED THORACOSCOPIC SURGERY FOR EARLY- STAGE NON-SMALL CELL LUNG CANCER AT VIET DUC UNIVERSITY HOSPITAL}

Background: Lung cancer is one of the most common cancers and the leading cause of death worldwide. Surgery is the treatment of first choice for early stage (I, II) non-small cell lung cancer including 